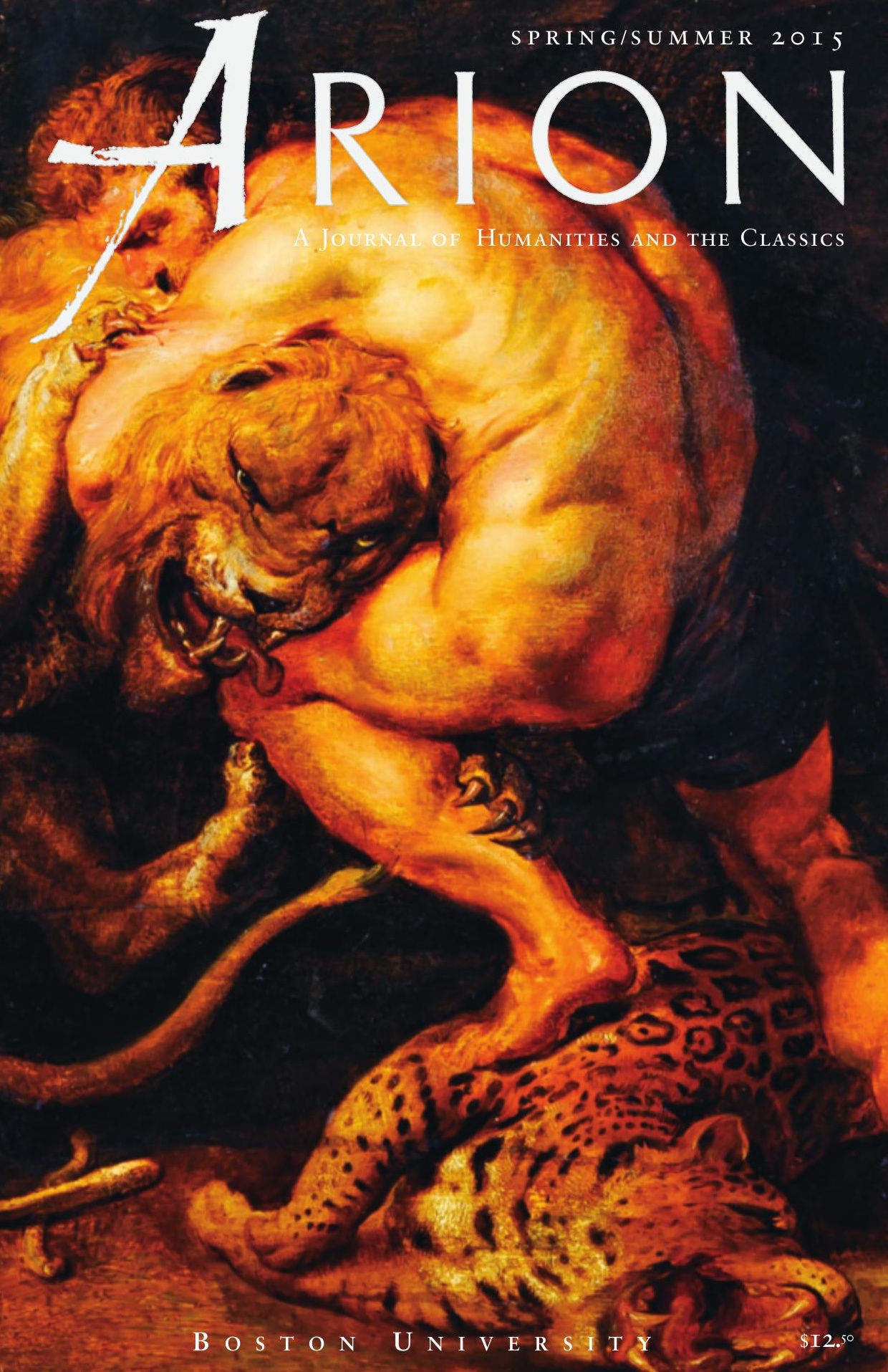




\title{
Grounded, Heracles and the Gorgon's Gaze
}

\author{
STEPHE HARROP
}

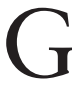

ROUNDED BY George Brant is a drama which explores the psychological consequences and moral implications of our increasing dependence upon remote hi-tech warfare. It takes the form of an extended monologue, in which The Pilot (we never learn her name) tells her own life story, from being a hot-shot F-I 6 flyer zooming over the skies of Iraq to the dislocation of piloting an Unmanned Aerial Vehicle (commonly known as a "drone") from Creech Air Force Base, just outside Las Vegas. The play was first produced by the Gate Theatre (London) in a production directed by Christopher Haydon. It previewed in London in July $20 \mathrm{I}_{3}$ before transferring to the Traverse Theatre as part of the Edinburgh Festival Fringe, and then returning to the Gate in September 20I3. This was followed by a revival in the spring of 20I4, transfers to The Studio Theatre (Washington, DC) and GEST (Sweden), and a UK tour in 20I4-I5. Grounded's official rolling world premiere (in three separate productions) took place in San Francisco, Tucson and Kansas City in autumn 20I3. As I make the final revisions to this piece, a new production of the play, directed by Julie Taymor and starring Anne Hathaway, has just opened at the Public Theater (New York).*

This essay, however, discusses Grounded in the specific context of the Gate's (London) production. It begins with a critical examination of my own "mis-seeing" of the play's protagonist as a version of the tragic Heracles. The analysis which follows compares key aspects of The Pilot's narrative

*George Brant's Grounded has most recently been directed by Julie Taymor, at the Public Theater, with Anne Hathaway in the starring role. Previews began April 7, 20I 5; it officially opened on April 26, running through May 24. 
with Euripides' Heracles and Sophocles' Women of Trachis, and relates my "mis-seeing” to Brant's referencing of symbols and characters from ancient Greek myth within the drama. It finally considers the Gate's staging of the play's closing moments in relation to the dramaturgy of Athenian tragedy, examining the ways in which the production denies its watchers the expected tragic spectacle of the fallen hero, instead foregrounding and interrogating the ethics of the audience's own spectatorship. ${ }^{\mathrm{I}}$

In Lucy Ellinson's acclaimed performance, The Pilot is an abrasive, brash and cocksure figure, narcissistically enraptured with her own military prowess. She begins by recalling her time flying over Iraq, reaching ("It's more") for the language that will allow her to articulate her sensuous delight in inhabiting "the blue":

You are the blue

You are alone in the vastness and you are the blue

Astronauts

They have eternity

But I have color

I have blue

However, her time in "the blue" is all too short. Home on leave, she meets a guy in a bar, and they spend three days together. Then The Pilot discovers she's pregnant, is sent home from the front-line, and (following the birth of her daughter, Sam) is re-assigned to a place in the "Chair Force" (30). Instead of flying daring solo missions far from home, she now pilots a machine she's never laid eyes on from the safety of the Nevada desert, commuting to and from work daily like any other mom:

I will get to fly again

Sort of

But I will not be eight thousand miles away while I do it

I will see my daughter grow up

I will kiss my husband goodnight every night 


\section{No tracer fire}

No RPGs

The threat of death has been removed

It is with this change of location, and with The Pilot's exile from "the blue" which has formerly defined her, that the tragedy of Grounded gets underway.

Brant's first reference to classical mythology also occurs at this moment, in the form of a lightning bolt pin that is attached to The Pilot's flight suit, which she initially rejects as symbolic of the despised "Chair Force," but gradually comes to adopt as totemic of her new, invulnerable status. 3 This lightning bolt brands its bearers as immortal, operating far beyond the reach of their enemies' weaponry. Wearing it, The Pilot becomes one of the "drone gods," possessed of a power so absolute that it sets her fumbling for mythic parallels:

Was it Olympus?

Is that right?

Olympus debates the fate of the lowly jeep

Who knew?

Olympus is a trailer in the middle of the desert

Deprived of her former pride in being an Fi 6 flyer, 4 The Pilot creates a new identity for herself and, inspired by the hi-tech invulnerability of her new posting, she increasingly comes to view herself as a figure out of ancient myth.5

However, The Pilot's assumption of a godlike identity soon shifts from joking affectation to a more serious register. When Eric, growing worried about his partner's inability to switch off outside of her flying hours, suggests counseling, his intervention is rejected with angry contempt:

Don't speak to me of guilt

Don't speak to a god of guilt

This god isn't interested okay?

This god wants a beer.

Her appropriation of an Olympian identity is accompanied by other unsettling symptoms of The Pilot's dislocation 
from her family. Entering Sam's bedroom to kiss her goodnight, she's alarmed by the child's appearance:

She's grey

She's grey she's grey she's grey

I grab her is she not breathing is she why is she grey why Why

She screams awake

Eric turns on the light

Color comes back

As the play's audience uneasily realizes, The Pilot's perceptions of her family's domestic space are being unsettled by her daily observation of the unreal "grey" desert combat zone which appears on her flight screen.

In a sense, Grounded's audience has already been primed for this development. From the outset, The Pilot's military vocation has been seen to threaten the safety of her daughter, even before Sam has emerged from the womb:

It's the ejection seat
What it boils down
'Cause an ejection
An ejection would
A G-Force abortion
I want the sky
I want the blue
But I can't kill her
I can't kill her
I can't

In this way, a potentially lethal contradiction between parenthood and The Pilot's warrior identity is established from the very early stages of Grounded. As the drama's sense of foreboding deepens, the tension between her Olympian / military and domestic / familial identities becomes ever more pro- 
nounced. As it does, I am reminded of the tragic Heracles, the quasi-divine hero, half Olympian and half human, whose triumphal homecoming spells death for his wife and his children.

The strategy of using ancient tragedy and epic to address the ethics and consequences of contemporary warfare has become a familiar one. The works of Jonathan Shay (Achilles in Vietnam, 1994 and Odysseus in America, 2002) have encouraged readers to identify resonances and interactions between the experiences of modern soldiers and the fighting men of ancient myth while (in the US) projects including Theater of War (Outside the Wire), You Stories and Warrior Chorus (Aquila Theatre) have used Greek texts and archetypes to help articulate the challenges facing homecoming veterans. ${ }^{6}$ In the UK, adaptations and appropriations of Greek myth have parachuted ancient tragedy's soldier protagonists into many modern-day trouble spots; deploying them in conflicts from Northern Ireland and the Balkans to Iraq, Afghanistan and Palestine. As Edith Hall has observed, such narratives seem to be "speaking louder than ever to our war-torn modern consciousness." 7

The violence of the tragic Heracles has similarly been dissected in a spate of millennial theater productions including Tony Harrison's The Labourers of Herakles (Delphi, I995), Kenneth McLeish's Herakles (Gate Theatre, I998), Ted Hughes' Alcestis (Nothern Broadsides, 2000), Simon Armitage's Mister Heracles (West Yorkshire Playhouse, 200I) and Martin Crimp's Cruel and Tender (The Young Vic, 2004). The drama has also seen a recent resurgence in US performances. Aquila Theatre's Herakles, first performed in 20I 2, is especially noteworthy in this context. ${ }^{8}$ As Kathleen Riley argues, these modern appropriations of the darker elements of the Heracles myth (especially those deriving from Euripides' Heracles) reveal an anxious fascination with "the trained killer who misdirects his aggression against his own household," and with the problem of "trained killers adapting to civilized and civilian society."9 Perhaps this is why I 
can't help but see The Pilot-the invulnerable warrior with Zeus' lightning pinned to her suit, the exasperated parent who can't turn off her aggression at the end of the working day-as one more modern-day Heracles. One more potential child killer, failing to reconcile being a god and a soldier with the mundane demands of family life. When the sleeping Sam begins to turn gray, like the assumed enemies targeted on The Pilot's monitor, I fear the worst.

The signifier by which Brant evokes this threat to The Pilot's child is also reminiscent of the ancient, tragic Heracles. After a twelve-hour shift with her eyes trained on the gray of the technologically mediated desert, The Pilot begins to perceive her own domestic surroundings as partaking of that same unreality. Her ability to distinguish between the landscapes of the conflict zone and the theoretically safe spaces of her own home is compromised. In Greek tragedy, the murderous madness of Euripides' Heracles is similarly presaged by the hero's inability to distinguish between his own domestic space and the locations inhabited by his enemies. ${ }^{\text {}} 0$ As the play's messenger reports, he "declared he'd come to Mykenai" although he was, in fact, "in the midst of his own house." The frenzied Heracles perceives wrongly, seeing "here" as "there." Thus, the father "with a blank Gorgon stare" murders his own children and wife, believing them to be the family of his foe. ${ }^{\text {II }}$

The "Gorgon stare" evoked in this moment is significant. As Vernant and Frontisi-Ducroux explain, "the gaze of the Gorgon, which sometimes gleams from the eyes of the frenzied warrior," strips its victims of agency, and "foretells impending, inevitable, death." 12 The image of the Gorgon is present, too, in Grounded. Grudgingly beginning to admire the complexity of the Reaper drone she'll be operating, The Pilot twice describes her plane as having a "Gorgon Stare" $(35,38)$, its gaze by implication not only observing but also threatening indiscriminate destruction to the populations whose lives are spied upon by hi-tech eyes in the sky. ${ }^{13}$ The gaze of the Gorgon is a fearsome weapon, both literally and 
figuratively capable of turning enemies into stone, or in the case of The Pilot into undifferentiated gray "putty" (38). However it can also impair the vison of those who employ its awesome fire-power. The gaze of the Gorgon mis-sees friends as enemies, and children as targets. ${ }^{\mathrm{I}} 4$

As it turns out, I'm not the only one to be worried about The Pilot's unreliable ability to distinguish between the front-line and the home. The unseen Eric is also alarmed by her behavior, especially her outbursts of anger provoked by Sam's failure to share her mother's macho, Olympian selfidentification:

Sam wakes up during dinner Sam wants to play with her ponies Those fucking ponies

I pick her up

Are you a hair-tosser after all Sam? Are you a hair-tosser?

Sam's confused

Eric takes her from me

Fine

But she should remember

She should remember the sky

The combat zone and the home she shares with Eric and Sam are too close together for The Pilot to be able to untangle her military and domestic experiences. ${ }^{15}$ "The desert isn't long enough," she complains:

Still have bodies in my head I orbit our block a few times

Hope Eric isn't looking out the window

Then I pull up and the door opens and the happy family greets their hero home from the war $(50-5 \mathrm{I})$

In another of Brant's gestures towards the play's ancient antecedents, The Pilot then observes:

It would be a different book

The Odyssey

If Odysseus came home every day 
Every single day

A very different book

This barbed allusion to the Odyssey becomes particularly ominous if the domestic carnage associated with Odysseus' homecoming is recalled. ${ }^{16}$ Arriving home still wearing her flying suit, still pumped with the excitement of killing-having wreaked righteously bloody havoc from the safety of a trailer in the Nevada desert-The Pilot threatens to personify that overspill of violence sanctioned for use elsewhere, which modern theater has repeatedly associated with the figure of the returning warrior from ancient myth.

Eric's solution is to offer The Pilot a gift, which he hopes will make her daily homecoming a less threatening event. His gift, left beside their bed, is labeled "For the drive home" (58), and when The Pilot slides the enclosed CD (marked "Decompression") into her car stereo she realizes that Eric's created a homemade mix of tracks designed to facilitate her mental transition from being a pilot to being a parent, beginning with AC/DC and ending with the saccharine tones of Sam's favorite song:

PONY SONG:

Where o where will we ride today

O the places we'll see

Where o where will we ride today

My pretty pony and me

(THE PILOT smiles, she's been given some relief.)

THE PILOT:

Eric

He's still got it

And it's perfect timing

The pony ride ends just as I pull into our drive

Home

I'm Home

Home

(6I-62)

Eric's gift is designed to defend his household against the 
threat posed by The Pilot's inability to leave the war behind. And, initially at least, it seems to be working. The audience laughs with The Pilot at the sickly-sweet incongruity of "The Pony Song." Our collective tension relaxes. The Pilot reads her daughter a bedtime story, calls her "my little girl" (62). Tragic expectations have been raised, and then side-stepped. We've been teased with the prospect that this latter-day Heracles will turn out to be another theatrical victim of combat trauma, one more tragic protagonist driven to family murder by extended exposure to extreme violence (the sex of this homecoming warrior perhaps lending piquancy to a well-worn trope). ${ }^{17}$ Then Grounded confounds this grisly expectation. ${ }^{\mathrm{I}}$

However, the sense of danger never entirely recedes: "She's a little grey as I walk out of her room" The Pilot notes, "but it's a trick / of the light the dark" (62). Nor does my feeling that I'm witnessing the unraveling of a sort of Heracles myth entirely fade. The story being told in the latter stages of Grounded may not be a Heracles-style tragedy of heroic carnage erupting within the domestic sphere, but increasingly the play resonates instead with Sophocles' Women of Trachis, in which a lovingly meant, double-edged gift threatens destruction to an apparently invulnerable hero. Like the poisoned garment Deianeira sends to Heracles in Sophocles' play, Eric's mix CD turns out to be a well-meaning gift which produces unexpected consequences. As the seepage between The Pilot's two lives increases, she decides to play the "Decompression" CD on the outward leg of her drive to work. Recklessly reversing the effect of Eric's gift, she steps into her military life singing along to the dying strains of "The Pony Song," having thrown her lightning bolt pin out of the car window along with "some other shit" (65). Instead of bringing her warrior persona into the family home, a trope dramatized by multiple modern productions of (or inspired by) the tragic myths of Heracles, Grounded's protagonist steps onto the front-line still wrapped up in the 
song most strongly associated with her maternal persona. In this inversion of tragic convention, the expected catastrophe is suddenly reversed. Sam, playing happily with her pony, now gifted with flight and re-named Pegasus in honor of her Olympian mother (64), is no longer the object of anxiety. But The Pilot, relentlessly pursuing an assumed terrorist across the gray desert, struggles with a new sort of slippage between her professional and personal identities, leading to a different moment of tragic "mis-seeing."

She has tracked a figure believed to be "the Prophet" (the second-in-command of an unnamed, implicitly terrorist, organization) for days, desperate for a chance to verify his identity, and to unleash the Olympian firepower which will "smite him down" (53).19 Today, though, the tracked car stops in front of a building, causing The Pilot's headset to burst into excited chatter: "this is his home this is where he keeps one of his wives one of his families this might be something” (65). But still “the Prophet” doesn't leave the protection of his vehicle. Not until:

A girl

A girl runs out of the house

Runs out towards the car

A little girl running

Her face her body blurs

And

Miracle

The car stops

The passenger door opens

The Prophet

The one-eyed Prophet walks out

Leaps out

Leaps limping towards her waving his arms

He's waving her away waving her away from the car trying to keep her safe

(66-67)

The appearance of the small girl offers The Pilot the opportunity she's obsessively pursued. Her strategic team call urgently for her to take the shot. But, still staring at the 
gray screen, The Pilot notices something wrong:

\author{
The girl \\ Her face \\ She stops running and I see it \\ Her face \\ I see it clearly \\ I can see her \\ It's Sam \\ It's not his daughter it's mine \\ It's Sam
}

The Pilot is frozen, unable to respond to the insistent commands of her Olympian superiors, only able to repeat, in an anguished echo of her earlier speech: "I can't kill her I can't kill her I can't” (67). Eric's double-edged gift has done its work only too well, fatally compromising his partner's warrior persona, rendering the Olympian hero helpless.

In this reversal of tragic expectations, the anticipated relationship between the front-line and the domestic is suddenly switched. We feared that The Pilot would misapply the violence sanctioned for use "there" within the "here" of her own home. However, the opposite has occurred. If Grounded's protagonist may be read as a kind of Heracles, then (in keeping with the play's reversal of conventional tropes) she's a maddened warrior hero who fights to avert the tragedy of child-killing, deliberately turning the "swollen belly" of her drone away from the far-away child who suddenly appears to share the features of her own daughter (68). At this moment of crisis, both The Pilot and her plane are refigured as maternal presences in the sky, impervious to the commands of the military hierarchy, exulting in the fact that, in defiance of tragic precedent, "I have saved my daughter" (68). If the distracted Heracles of Euripides' tragic drama inflicts the brutal death intended for his enemies upon his own children, and the tormented Heracles in Women of 
Trachis calls for flames that will burn away the mortal part of him, emerging wholly divine, then Brant's Heracles chooses, by contrast, to sacrifice the Olympian half of her contested identity, ${ }^{20}$ destroying her military career in an anguished instant of determination to save her enemy's child, temporarily indistinguishable from her own daughter. The hi-tech unreality of the "simulacrum of war" inhabited by The Pilot has proved to be a zone profoundly vulnerable to the kind of tragic "mis-seeing" associated with the influence of the Gorgon's gaze. ${ }^{2 \mathrm{I}}$

In Euripides' Heracles, the hero's response to his dawning awareness of his own bloody actions is to hide himself from view. Anne Carson observes that the grieving hero's "task in the last third of the play is to rise from this prostration," and it is Theseus who eventually insists that he be revealed, instructing him to "Stand up. Uncover your poor head." 22 Under Theseus' tutelage, the grieving Heracles is coaxed into presenting himself to the massed gaze of the theatron (literally a "seeing place") where he stands as an emblem of the gods' indifference, and the possibility of human endurance. Likewise, in Women of Trachis, the dying Heracles demands: "All of you, fasten your eyes on this tormented frame." ${ }_{23}$ In both cases, the broken hero is explicitly framed as a figure to be looked at. However, as might have been expected from the drama's consistent inversion of tragic tropes, Brant's protagonist in Grounded responds differently, a fact which is exploited to uncompromising effect in the final moments of the Gate's production.

Instead of making its grief-stricken protagonist the object of an audience's fearful or pitying gaze, the final moments of the Gate's Grounded bring the full intensity of the drama's own gaze to bear upon its gathered watchers. Throughout the performance, the audience has been staring intently at The Pilot/Lucy Ellinson, who's standing on a small raised stage in the centre of the theater-space, surrounded on three sides by close-packed spectators, who peer at her through the walls of the fine gauze cube (designed by Oliver 
Townsend, and lit by Mark Howland) which she inhabits throughout. However, in the production's final moments this relationship alters, as The Pilot eyeballs her audience, joltingly re-contextualized as her captors, spying on her prison via the very technologies she used to command the gray desert. The Pilot (the walls of the cube now become the limits of her cell) addresses the audience directly, identifying us as:

You who watch me

Who observe me watch my every move here and I know you watch me I know there is a camera somewhere for

Everything is Witnessed

Only too familiar with the habits of the all-seeing Olympians she once served, The Pilot challenges the collective gaze that she knows is trained upon her. As she does so, the audience becomes the looked-at. The Pilot's furious gaze refigures us as the guilty ones, just as her direct address arraigns the gathered watchers in the dark, the voyeurs of her grief, who have passively watched the tragedy being played out before them. "Know That You Are Not Safe" she demands, pacing the confines of her prison, never more than a few feet from her watchers (70). It's an irony of contemporary theatrical artifice that Ellinson can't see us at this moment, since she is brightly lit and we are in darkness. ${ }^{24}$ But as she glares out of her prison, it certainly feels as though she can, and the implications of The Pilot's words, her baleful, accusing gaze, are all too clear. We London theatergoers, facing one another across the Gate's tiny auditorium, have permitted these things to be done in our names. We have watched (or not watched, strategically unseeing) as drones have turned their Gorgon gaze upon other peoples and places. However, as Grounded's Heraclean echoes remind us, the Gorgon doesn't distinguish friend from foe. The watchers may become the watched. "There" may one day become "here." 25

In Stage Fright, Animals and Other Theatrical Problems 
(2006) Nicholas Ridout considers such moments from the point of view of the spectator, for whom scrutiny from the stage is often experienced as a disruptive violation of the safe, dark space of the auditorium. In Ridout's analysis, the actor's direct gaze is capable of generating intense embarrassment among audience members because it suddenly makes us see ourselves as we are seen by another, to "appear" in terms which are externally defined, and unrelated to our own private sense of self. For Ridout, this unpleasant shock is "capable of activating in an audience a feeling of our compromised, alienated participation in the political and economic relations that make us appear to be who we are." ${ }^{26}$ In the closing moments of Grounded, the audience's "appearance" is defined by The Pilot's words: We are (and can only be) "You who watch me" (70). The dominant conditions of western, bourgeois theater-going (including the audience's assumed silence) allow spectators no means of protest or self-defense, no way of asserting individuality, innocence, or virtuous intent. Trapped by the play's "reverse gaze," 27 we experience a temporary loss of agency which forces a privileged London theater audience to taste (if only for an instant) something of the discomfort of existence beneath the Gorgon's gaze.

In recent years the Gate has been home to a series of performances based on, or responding to, Greek myth and tragedy, all of them in productions keenly alert to the challenges and dramatic potential represented by the venue's intimate dimensions (the theater seats only seventy-five). In The Trojan Women (2012, written by Caroline Bird and directed by Christopher Haydon) the indignation, terror and rage of Lucy Ellinson's one-woman chorus all but scorched spectators near enough to reach out and touch her, provoking an uneasy awareness of our own incongruous (even obscene) inactivity in relation to her suffering. In 20I4, Idomeneus (Roland Schimmelpfennig's text translated by David Tushingham, and directed by Ellen McDougall) playfully explored an audience's potential complicity in atrocious acts, 
with smiling actors handing out innocent-looking glasses of water which would later be reframed onstage as murder weapons. Given this context, it's not surprising that Grounded's creative team should respond with acuity, and with uncompromising political intent, to The Pilot's refusal to figure herself as a tragic spectacle. Instead, in the play's final moments, the Gate's production powerfully and combatively foregrounds the ethical implications of its audience's own watching, witnessing, and "mis-seeing" of contemporary warfare. ${ }^{28}$

\section{NOTES}

I. Nicholas Ridout cautions against the convention by which the word "we" is used, in writing about theater, "in order to scale up the experience of a single spectator into an experience that may be imagined as having been shared by others, by an audience." Nicholas Ridout, Passionate Amateurs: Theatre, Communism and Love (Ann Arbor 20I3), 2. This essay attempts to evoke my own (internal) witnessing of audiences engaged in watching a play which probes the ethics of observation, and in which the audience as a whole arguably stands indicted of voyeurism, and worse. My choice of the words "we," "us" and "our" at particular moments reflects these concerns, but does not imply that my own response to the play should be taken as representative, or neutral. On the dangers of generalizing about audiences' responses, see Helen Freshwater, Theatre \& Audience (Basingstoke 2009).

2. George Brant, Grounded (London 20I3). All references are to this edition.

3. The lightning bolt (or thunder bolt) is a common feature of USAF insignia, sometimes explicitly linked with the Roman Jupiter, and often taken as representing speed and/or airborne striking power. Such usage falls within Settis' critique of "classical" culture being used "by Western civilization to claim its superiority over other civilizations." Salvatore Settis, The Future of the "Classical," Allan Cameron, trans. (Cambridge 2006), 3.

4. On The Pilot as a "self-drawn heroic figure" see further Dan Hutton, "Interview: Lucy Ellinson” (5 May 20I4). http://dan-hutton.co.uk/20I4/05/05/interview-lucy-ellinson/(accessed 7 July 20I4).

5. On the "God-like" view of drone pilots, and its psychological consequences, see Medea Benjamin, Drone Warfare: Killing by Remote Control (London 2013), 90.

6. See further Peter Meineck, "“These are men whose minds the Dead have ravished": Theater of War/The Philoctetes Project." Arion I7.I (2009). Also Peter Meineck and David Konstan, eds, Combat Trauma and the Ancient Greeks (New York 20I4). Lorna Hardwick, "Against the 
'Democratic Turn': Counter-texts; counter-contexts, counter-arguments" in Lorna Hardwick and Stephen Harrison, eds, Classics in the Modern World: A Democratic Turn? (Oxford 2013), 2I-23, offers a thought-provoking response to such projects.

7. Edith Hall, "Aeschylus, Race, Class, and War in the I990s," in Edith Hall, Fiona Macintosh and Amanda Wrigley, eds, Dionysus Since 69: Greek Tragedy at the Dawn of the Third Millennium (Oxford 2004), I73. See also Edith Hall, "Why Greek Tragedy in the Late Twentieth Century?," in the same volume, I 8-22.

8. For a discussion of this production see Amy R. Cohen and John H. Starks, "A Conversation About the Aquila Herakles." Didaskalia I0.06 (20I3). http://www.didaskalia.net/issues/Io/6/ (accessed 7 July 20I4).

9. Kathleen Riley, The Reception and Performance of Euripides' Herakles (Oxford 2008), I I 4; I 27.

Iо. A similar "mis-seeing” afflicts the Ajax of Sophocles' tragedy, maddened by the "gorgon-eyed daughter of Zeus," Sophocles: Four Tragedies, Peter Meineck and Paul Woodruff, trans. with intro. and notes, (Indianapolis 2007), 23. Ajax has been the subject of several recent theatrical adaptations exploring the psychological consequences of ancient and modern warfare. Ellen McLaughlin's Ajax in Iraq (Flux Theater Ensemble, 20I I) was inspired by material collected from interviews with Iraq war veterans, and drew explicit parallels between the ancient hero's madness and the stress and brutality of contemporary military service. Timberlake Wertenbaker's Our Ajax (Southwark Playhouse, 2013) also made use of the testimonies of modern-day veterans. Wertenbaker's Ajax was played by Joe Dixon, who had previously originated the role of The General (the 'Heracles' figure) in Martin Crimp's Cruel and Tender.

I I. Anne Carson, Grief Lessons: Four Plays (New York 2006), 59-60. See also Carson, 26; 55. The preface to Carson's poetically incisive (rather than strictly literal) rendering of Euripides describes tragedy as a space which permits unbearable grief and rage to "play itself out without you or your kin having to die," 7 . She highlights the impact of the Peloponnesian war, with its "corruption, distortion, decay and despair," upon the ancient playwright's creativity, asserting that Euripides made his revisionary versions of heroic warrior myths "to refract his observations of this woe," 8.

I2. Jean-Pierre Vernant and Françoise Frontisi-Ducroux, "Features of the Mask in Ancient Greece," in Jean-Pierre Vernant and Pierre Vidal-Naquet, Myth and Tragedy in Ancient Greece, Janet Lloyd, trans. (Brooklyn 2006), I9I.

I3. "Gorgon Stare" is also the name given to a real airborne surveillance system used by the US Air Force. See further Benjamin (note 5), 2I; 48-49. See also Ellen Nakashima and Craig Whitlock "With Air Force's Gorgon Drone 'we can see everything"” (2 January 20II).http://www.washingtonpost.com-/wpdyn/content/article/2OI I/OI/OI/AR2OI IOIOIO2690.html (accessed 22 November 20I4).

I4. For several instances of drones "mis-seeing," including mistaking 
children for enemy combatants, see Benjamin (note 5), 27-28; 9I-94; I64; 208.

I 5. On the problem of "decompressing" see Benjamin (note 5), 83-85; 9I; 95; 97.

I6. Shay remarks that "Odysseus has shown us how not to come home from war." Jonathan Shay, Odysseus in America: Combat Trauma and the Trials of Homecoming (New York 2002), I49. See further Shay, I20-46.

I7. For a discussion of comparative representations of Medea and Heracles as child-killing parents see Kathleen Riley, "Heracles as Dr Strangelove and GI Joe: Male Heroism Deconstructed," in Edith Hall, Fiona Macintosh and Amanda Wrigley, eds, Dionysus Since 69: Greek Tragedy at the Dawn of the Third Millennium (Oxford 2004), I3-I 5.

I8. Carson's analysis of Euripides' tragedy may be apposite here: "Herakles is a two-part man. Euripides wrote for him a two-part play. It breaks down in the middle and starts over again as does he. Wrecks and recharges its own form as he wrecks and recharges his own legend." Carson (note II), I3. See also Riley 2008, 30-38.

I9. In the light of The Pilot's self-identification with Odysseus earlier in the play, this one-eyed enemy might perhaps be considered a Cyclopean figure, though such a comparison is not explicitly made within Brant's text.

20. In this she resembles the hero of Euripides' Heracles, who tells Amphitryon "I consider you / my father now, not Zeus." Carson (note II), 76-77.

2I. Jean Baudrillard, The Gulf War Did Not Take Place, Paul Patton, trans. (Bloomington I995), 25.

22. Carson (note II), I6; 74 .

23. Meineck and Woodruff (note I0), I07.

24. A detail mentioned in Hutton's $20 \mathrm{I} 4$ interview with Ellinson (note 4).

25. On the subject of drone proliferation, see Benjamin (note 5), 70-82.

26. Nicholas Ridout, Stage Fright, Animals, and Other Theatrical Problems (Cambridge 2006), 93-94.

27. Ridout (note 26), 88.

28. I am grateful to Clare Slater and Richard Rowland for their comments on the final draft of this piece. 


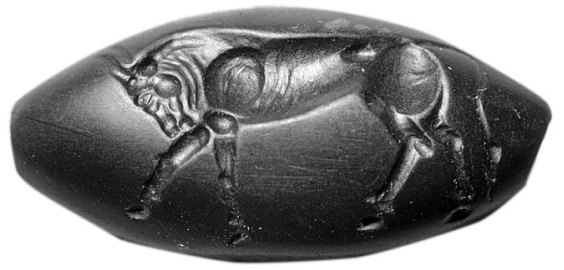




\section{INSIDE THIS IsSUE:}

\section{Paradigms for Today's Politics:}

TheOdore Ziolkowski on Aeschylus

232. KAREN SIMONS reflects on family, life and translation >का

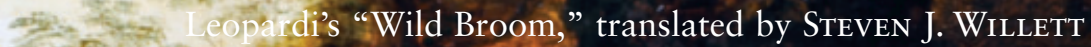
तit.

28 NIKLAS HOLZBERg recounts the story of the Weiße Rose in Munich, I94I-45

Hypatia, 4I5 CE," a poem by Joan Alice Wood Kimball

ANDREA Nightingale on the "I" and "Not I" in Augustine's Confessions

A. M. JUSTER translates from Maximianus' Elegies

Django Unchained and Terence's Eunuchus:

RICARDO APOSTOL on slavery and the American imagination

BROOKE CLARK translates from The Greek Anthology

Avi SHARON on Durrell, Warner and Katsimbalis

Five poems by KaRL KIRCHWEY

HERBERT GOLDER offers some further unmodern observations Jan Kott and Ben Power, reviewed by J. Michael Walton

Stephe Harrop on George Brant's Grounded

IGGY Pop discovers Gibbon's Rome in America 